\title{
Article \\ Investigation of Biocompatible PEO Coating Growth on cp-Ti with In Situ Spectroscopic Methods
}

\author{
Veta Aubakirova ${ }^{1}$, Ruzil Farrakhov ${ }^{1}\left(\mathbb{D}\right.$, Arseniy Sharipov ${ }^{1}$, Veronika Polyakova ${ }^{2}\left(\mathbb{D}\right.$, Lyudmila Parfenova ${ }^{3}(\mathbb{D})$ \\ and Evgeny Parfenov $4, *$ (D) \\ 1 Department of Electronic Engineering, Ufa State Aviation Technical University, 12 Karl Marx Street, \\ 450008 Ufa, Russia; veta_mr@mail.ru (V.A.); frg1982@mail.ru (R.F.); arsenyarseny36728@gmail.com (A.S.) \\ 2 Institute of Physics of Advanced Materials, Ufa State Aviation Technical University, 12 Karl Marx Street, \\ 450008 Ufa, Russia; polyakova.vv@ugatu.su \\ 3 Department of General Chemistry, Ufa State Aviation Technical University, 12 Karl Marx Street, \\ 450008 Ufa, Russia; luda_parfenova@mail.ru \\ 4 Department of Biomedical Engineering, Ufa State Aviation Technical University, 12 Karl Marx Street, \\ 450008 Ufa, Russia \\ * Correspondence: parfenov.ev@ugatu.su; Tel.: +7-908-350-50-32
}

check for updates

Citation: Aubakirova, V.; Farrakhov, R.; Sharipov, A.; Polyakova, V.; Parfenova, L.; Parfenov, E. Investigation of Biocompatible PEO Coating Growth on cp-Ti with In Situ Spectroscopic Methods. Materials 2022, 15, 9. https://doi.org/10.3390/ ma15010009

Academic Editors: Alenka Vesel and Marek M. Kowalczuk

Received: 11 November 2021 Accepted: 16 December 2021 Published: 21 December 2021

Publisher's Note: MDPI stays neutral with regard to jurisdictional claims in published maps and institutional affiliations.

Copyright: (c) 2021 by the authors. Licensee MDPI, Basel, Switzerland. This article is an open access article distributed under the terms and conditions of the Creative Commons Attribution (CC BY) license (https:/ / creativecommons.org/licenses/by/ $4.0 /)$.

\begin{abstract}
The problem of the optimization of properties for biocompatible coatings as functional materials requires in-depth understanding of the coating formation processes; this allows for precise manufacturing of new generation implantable devices. Plasma electrolytic oxidation (PEO) opens the possibility for the design of biomimetic surfaces for better biocompatibility of titanium materials. The pulsed bipolar PEO process of $\mathrm{cp}$-Ti under voltage control was investigated using joint analysis of the surface characterization and by in situ methods of impedance spectroscopy and optical emission spectroscopy. Scanning electron microscopy, $\mathrm{X}$-ray diffractometry, coating thickness, and roughness measurements were used to characterize the surface morphology evolution during the treatment for $5 \mathrm{~min}$. In situ impedance spectroscopy facilitated the evaluation of the PEO process frequency response and proposed the underlying equivalent circuit where parameters were correlated with the coating layer properties. In situ optical emission spectroscopy helped to analyze the spectral line evolutions for the substrate material and electrolyte species and to justify a method to estimate the coating thickness via the relation of the spectral line intensities. As a result, the optimal treatment time was established as $2 \mathrm{~min}$; this provides a 9-11 $\mu \mathrm{m}$ thick PEO coating with Ra $1 \mu \mathrm{m}, 3-5 \%$ porosity, and containing $75 \%$ of anatase. The methods for in-situ spectral diagnostics of the coating thickness and roughness were justified so that the treatment time can be corrected online when the coating achieves the required properties.
\end{abstract}

Keywords: functional biocompatible coating; plasma electrolytic oxidation; microdischarges; process diagnostics; optical emission spectroscopy; in-situ impedance spectroscopy

\section{Introduction}

The world market of orthopedic implants is constantly growing due to the aging population [1]. The most preferred materials for reconstructive surgery in orthopedics are titanium alloys, which are used for the production of screws, fixation plates, scaffolds, and other internal devices [2]. However, titanium itself does not show bioactive properties, and commercially used alloys such as Ti-6Al-4V contain harmful alloying elements; therefore, the implant surface must be functionalized with a corrosion resistant and bioactive coating [3,4]. Otherwise, the surface will not properly interact with the osteoblast cells, and a foreign body reaction and inflammation would either slow the implant integration or cause implant rejection [5]. This complex problem in the area of functional materials can be solved by a proper design of the chemical and phase composition, and morphology of the coating [6]. The biomimetic approach appears to be the most fruitful decision of this problem $[7,8]$. 
Plasma electrolytic oxidation (PEO) is one of the promising methods for the biomimetic coating formation on the surface of light alloys including titanium $[9,10]$. This method affords obtaining a ceramic porous coating on $\mathrm{Al}, \mathrm{Ti}, \mathrm{Zr}, \mathrm{Mg}$, $\mathrm{Nb}$, and other valve metals [11-14]; the coating properties can be controlled by the variation of the process parameters and electrolyte composition as well as through the realization of the process control techniques [15-17]. Such morphology provides a gradual change in the elasticity modulus from the metal substrate to the bone; this addresses the biomimetic requirements at the mechanical level. The porous morphology has a bone-like structure, therefore, it provides close to the natural conditions for the osteoblast attachment and contributes to the biomimetic requirements at the physical level [7]. By introducing bioactive species and elements such as hydroxyapatite, silver, silicon, magnesium, fluorine, and others, the PEO process can address the biomimetic requirements at the chemical level on all implantable materials such as $\mathrm{Ti}, \mathrm{Mg}$, and others [18-21]. As previously shown, cp-Ti surface biofunctionalization with a titania PEO coating and organic molecules appears to be more effective than the formation of Ca- and P- containing inorganic PEO coatings [22]. Therefore, this research focuses on a titania PEO coating for $\mathrm{cp}-\mathrm{Ti}$ as a substrate for further modification with the bioactive organic molecules addressing the biomimetic requirements at the biological level [23].

The early stages of the PEO process predefine the quality of the resultant coating [24]. Therefore, an in-depth evaluation of the PEO process and resultant coatings during the treatment are crucial for the development of a high-quality biocompatible coating. Nowadays, investigations into the early stages of the Al [25], Mg [26,27], and Ti [28,29] PEO show new insights into the process mechanism. Due to the different electric regimes, not all results are comparable. PEO of Ti can be preformed in direct current (DC) [30], pulsed unipolar DC [31], and pulsed bipolar [32] regimes; all regimes can be realized either under current [33] or voltage control [34] and the combination of the regimes, and voltage ramping is also possible [35]. However, the question of the optimal PEO process duration and methods to understand in situ whether or not the process should be stopped is still open, especially for the treatment of titanium alloys under the voltage control. Previously, various diagnostic methods based on electrical and optical characteristics of the PEO process have been developed [36-39]. The in-depth evaluation of the PEO coatings via complex in situ electric diagnostics in both unipolar and bipolar regimes has recently been presented [40]. These methods include in situ impedance spectroscopy, which helps to justify the equivalent circuit of the system "metal-oxide-microdischarge-electrolyte" [41], and optical emission spectroscopy, which provides the emission intensities of the substrate and electrolyte species and facilitates estimation of the coating thickness [42].

Therefore, the aim of this research was to investigate the PEO coating growth on $\mathrm{cp}$-Ti under the voltage control through the analysis of the surface morphology, coating thickness, roughness, and phase composition in comparison with the results of the in situ spectroscopic methods to estimate the optimal treatment time that provides a biocompatible coating suitable for the realization of the biomimetic approach. The scientific novelty of this research is the justification of the coating thickness diagnostic methods so that the treatment time can be corrected online when the coating achieves the desired properties.

\section{Materials and Methods}

\subsection{Plasma Electrolytic Oxidation}

The PEO process was realized using automated equipment with computer control (USATU, Ufa, Russia) in pulsed bipolar regime under voltage control at positive voltage pulse magnitude $U_{p}=470 \mathrm{~V}$, negative $U_{n}=-40 \mathrm{~V}$ and duty cycles of the positive pulse of $51 \%$, negative pulse of $26 \%$, with symmetrical pauses were $11.5 \%$ of the cycle. The frequency was fixed at $300 \mathrm{~Hz}$. To have a soft start of the PEO process, the pulse voltage was ramped from zero to the setpoint value during $45 \mathrm{~s}$, then the voltage was kept at the setpoint. The process duration was $45,60,90,120,180,240$, and $300 \mathrm{~s}$. The voltage and current waveforms, root mean square (RMS), and average values were recorded using a 
data acquisition system operating at $\mathrm{f}_{\mathrm{s}}=1 \mathrm{MHz}$; the waveforms $\mathrm{T}=200 \mathrm{~ms}$ long were recorded every $\Delta \mathrm{t}=1000 \mathrm{~ms}$.

The samples were made of Grade 4 titanium (VSMPO-AVISMA, Verkhnyaya Salda, Russia, ASTM B 348, composition: C-max $0.08 \%$, O-max $0.40 \%, \mathrm{~N}-\max 0.05 \%, \mathrm{H}-\max$ $0.015 \%, \mathrm{Fe}-\max 0.50 \%$, other-max $0.4 \%$ total, Ti-balance) in a disk shape with the diameter of $10 \mathrm{~mm}$ and thickness of $1 \mathrm{~mm}$. The samples were polished with $\mathrm{SiC}$ paper to achieve Ra $0.1 \mu \mathrm{m}$. The current was supplied via a wire attached to a small hole at the sample edge; the wire was insulated with an epoxy resin. The electrolyte was $20 \mathrm{~g} / \mathrm{L}$ $\mathrm{Na}_{3} \mathrm{PO}_{4} \cdot 12 \mathrm{H}_{2} \mathrm{O}$; its temperature was kept at $20 \pm 2{ }^{\circ} \mathrm{C}$. The electrolyzer was a $6 \mathrm{~L}$ plastic tank with a stainless steel coil at the perimeter serving both as a heat exchanger and a counter-electrode. The electrolyte volume was $4 \mathrm{~L}$; a magnetic stirrer was used for the electrolyte circulation.

\subsection{In Situ Impedance Spectroscopy}

In situ impedance spectroscopy was performed in separate PEO experiments with the frequency sweep according to the method described elsewhere $[36,43,44]$. The equipment details and calibration have been previously discussed [45]. A step scan was used in the range from $20 \mathrm{~Hz}$ to $10 \mathrm{kHz}$. The scan frequencies were evenly distributed in the log scale: $28,38,62,101,164,268,435,713,1161,1845,3137,4481,7843$, and 10,457 Hz. Each frequency was applied to the PEO electrolyzer for $\mathrm{T}=2 \mathrm{~s}$; therefore, the sweep duration was $\Delta \mathrm{t}=28 \mathrm{~s}$. During each frequency step $T$, two acquisition frames of $T_{a}=500 \mathrm{~ms}$ were recorded at the sampling frequency $f_{s}=1 \mathrm{MHz}$, which is well above the Nyquist requirement for the highest frequency of $2 \times 10,457 \mathrm{~Hz}$. Therefore, temporal and spectral resolutions of the in situ impedance spectra estimates correspond to $\Delta \mathrm{t}=28 \mathrm{~s}$ and $\Delta \mathrm{f}=28 \mathrm{~Hz}$, respectively. As shown elsewhere, their product $\Delta \mathrm{t} \times \Delta \mathrm{f}=1$ [46].

The resultant in situ impedance spectra were processed with the earlier developed software FRAnalysis [41]; the equivalent circuit fitting was performed in ZView (Scribner Associates, Southern Pines, NC, USA).

The PEO process impedance was analyzed as a complex-valued estimate, with slowly time varying modulus $|Z|$ and phase angle $\theta$ :

$$
\underline{Z}=Z^{\prime}+j \cdot Z^{\prime \prime}=|Z| \cdot e^{j \cdot \theta},(j=\sqrt{-1}) .
$$

\subsection{In Situ Optical Emission Spectroscopy}

Optical emission spectroscopy was performed using an AvaSpec-ULS2048-USB2-UA50 fiberglass spectrometer (Avantes B.V., Apeldoorn, The Netherlands) providing the measurements in the range from 180 to $1100 \mathrm{~nm}$. The optical emission from the PEO tank was delivered by an optical fiber cable, which was housed in the electrolyte in an L-shaped glass tube (USATU, Ufa, Russia) with a quartz window at the end. The distance between the receiving window and the sample was $30 \mathrm{~mm}$. The spectrum integration time was $1 \mathrm{~s}$, which corresponds to the temporal resolution of the method. The spectra were processed using AvaSoft software (Avantes B.V., Apeldoorn, The Netherlands) supplied with the spectrometer. The spectral lines were identified using the NIST atomic spectra database [47]. The optical emission spectroscopy experiments were performed with a simultaneous video recording of the PEO process using samples $10 \mathrm{~mm} \times 40 \mathrm{~mm}, 1 \mathrm{~mm}$ thick.

According to the method in [42], to estimate the coating thickness, the emission intensities of two characteristic peaks were used: $I_{1}$-for a component of the electrolyte and $I_{2}-$ for the substrate material. The coating thickness can be evaluated as:

$$
h=k_{1} \cdot\left(\ln I_{1}-\ln I_{2}\right)+k_{2},
$$

where $k_{1}$ and $k_{2}$ are the calibration coefficients. In this study, sodium peak Na II at $817.986 \mathrm{~nm}$ was used to calculate $I_{1}$, and the titanium peak Ti I at $453.501 \mathrm{~nm}$ was used for $I_{2}$. 


\subsection{Surface Characterization}

The coating morphology was studied in top view and in cross-sections using a JSM6490LV (JEOL, Tokyo, Japan) scanning electron microscope (SEM). The coating porosity and pore size distribution were obtained with ImageJ software in accordance with ASTM E11210. Furthermore, the pore size distribution was fitted with lognormal distribution, whose mean was interpreted as the mean pore diameter. The coating thickness was measured with a Positector 6000 (Defelsko, Ogdensburg, NY, USA) eddy current gauge with an $\mathrm{N}$-type sensor with an accuracy $\pm 0.1 \mu \mathrm{m}$; the thickness was also verified by the analysis of the coating cross-sections. The surface roughness was measured with TR-220 stylus profilometer over the track length $0.5 \mathrm{~mm}$. Ra, $\mathrm{Rp}$, and $\mathrm{Rv}$ parameters were analyzed. The phase composition of the coatings was evaluated using X-ray diffractometer (XRD) Ultima IV, (Rigaku, Tokyo, Japan) in $\mathrm{Cu}-\mathrm{K} \alpha$ radiation, from 20 to 80 degrees $2 \theta$, using step scan every 0.02 degrees and dwelling time $1 \mathrm{~s}$. The XRD spectra were analyzed using Philips XPert software (Philips, Amsterdam, The Netherlands); a semiquant algorithm was employed for the quantitative analysis.

\section{Results}

\subsection{Electric Characteristics and Microdischarge Appearance during PEO of Ti}

Figure 1 shows the evolution of the RMS voltage and current during the PEO treatment. For each duration of interest, the photo of the microdischarges is shown. The color and the size of the microdischarges change with time: from small white numerous sparks to large yellow sparse "microarcs" (Figure 1a). The initial stages of the PEO process correspond to the voltage ramping during $45 \mathrm{~s}$ (Figure $1 \mathrm{~b}$ ). The current density shows complex behavior: growth for the voltage from 0 to $70 \mathrm{~V}$, then a passivation region from 70 to $150 \mathrm{~V}$, followed by the current decrease in the range of voltages from 150 to $200 \mathrm{~V}$, then a sharp increase due to the avalanche microdischarge ignition.

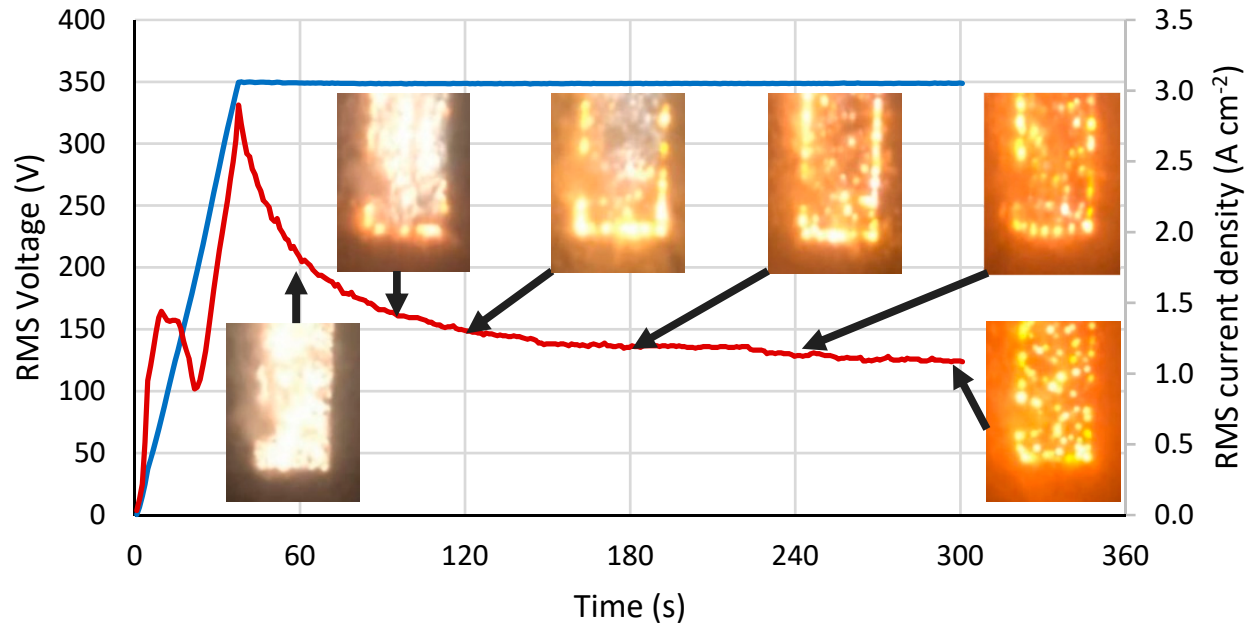

(a)

Figure 1. Cont. 


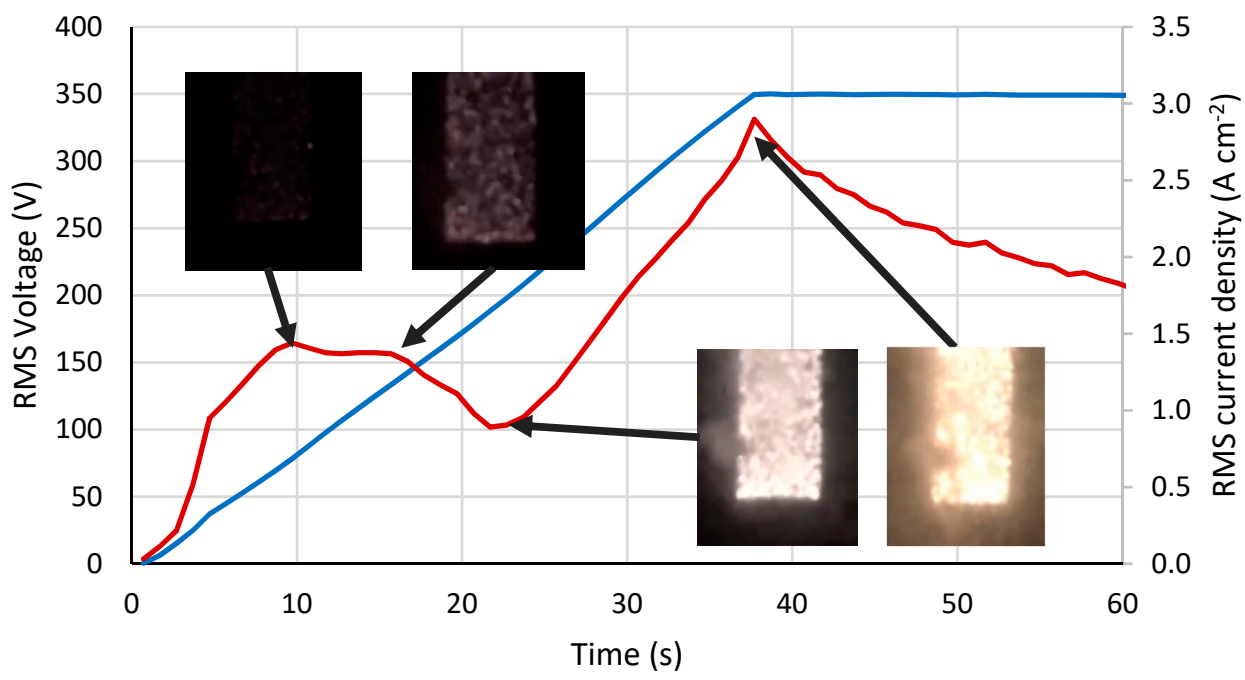

(b)

Figure 1. Evolution of RMS values of the voltage (blue) and current density (red), and microdischarges during the PEO process: (a) during all the treatment time; (b) during the initial stage of the process.

Two competing processes—anodic dissolution and oxide growth—explain the passivation behavior; the second process is prevailing at this stage, and the current stabilizes and even decreases with the voltage growth [26]. This stage is accompanied with the sample chemoluminescence, which gradually highlights the gas bubbles on the surface [48]. The following stage of the microdischarge ignition shows an almost linear current uprise with the voltage growth. The microdischarges significantly increase the conductivity of the system and contribute to the rapid coating growth [10]. By reaching the process steady state after the voltage ramp is over, the current gradually decreases with time; this indicates that the coating gains its thickness, and consequently, electrical resistance. The size of the microdischarges increases as a thicker coating requires more energy for the breakdown of the film.

\subsection{Evolution of Surface Morphology and Phase Composition during PEO of Ti}

The PEO coating morphology in top view and in cross-sections at each duration of interest is shown in Figures 2 and 3. Starting from $45 \mathrm{~s}$, the coating showed a porous morphology. The pore size distribution is depicted in Figures 2 and 3 for each image; the most numerous pores had diameters under $1 \mu \mathrm{m}$. The most rapid growth of the coating occurred during the first $120 \mathrm{~s}$ of the process (Figure 2). Furthermore, the growth rate decreased, and the coating became larger through the pores and a network of cracks could be seen in the cross-sections.

Figure 4 demonstrates the evolution of the PEO coating phase composition with the treatment time. The XRD revealed the peaks belonging to the Ti substrate, and two phase modifications of titania: anatase and rutile. Thinner coating at 45-60 s showed predominantly anatase peaks (101 at $25.325 \mathrm{deg}$. $2 \theta$ ). Rutile peaks (110 at $27.434 \mathrm{deg}$. 20) gradually increased with the treatment time. Since rutile is a higher-temperature phase than anatase, larger microdischarges at the final stages of the PEO provide higher temperatures and the rutile content in the PEO coating increased. 


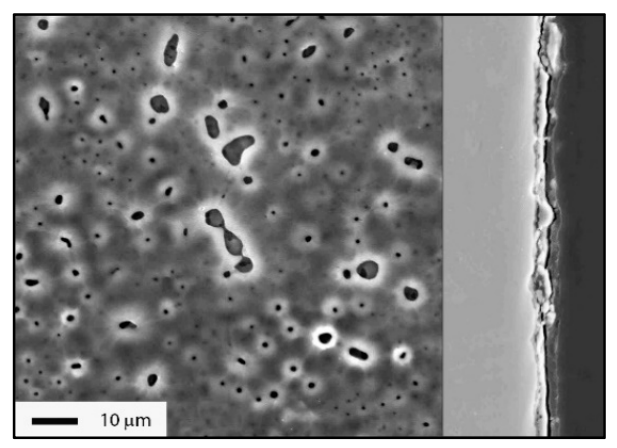

(a)

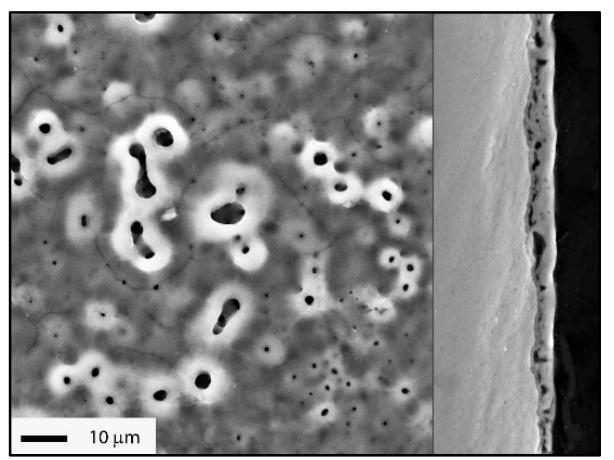

(c)

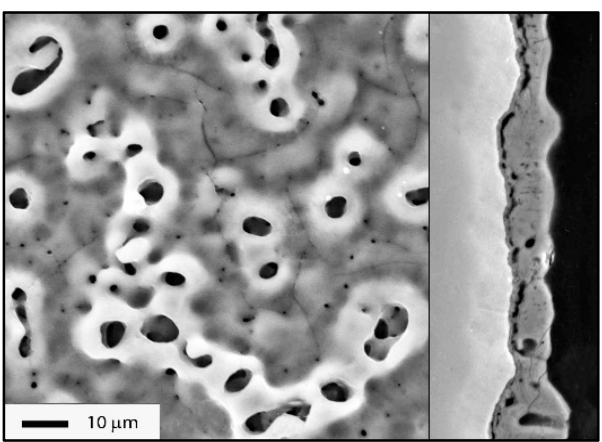

(e)

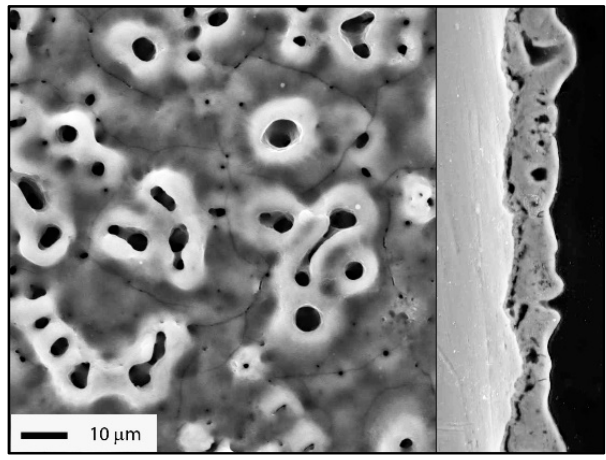

(g)

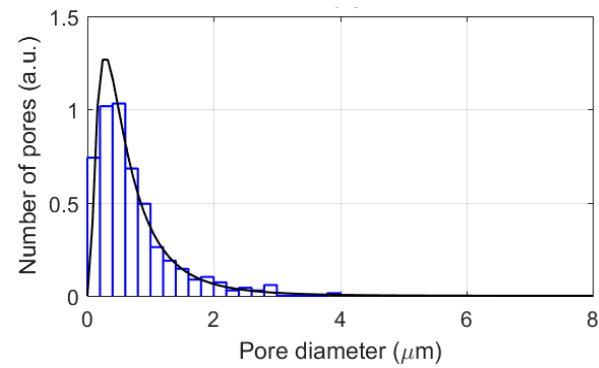

(b)

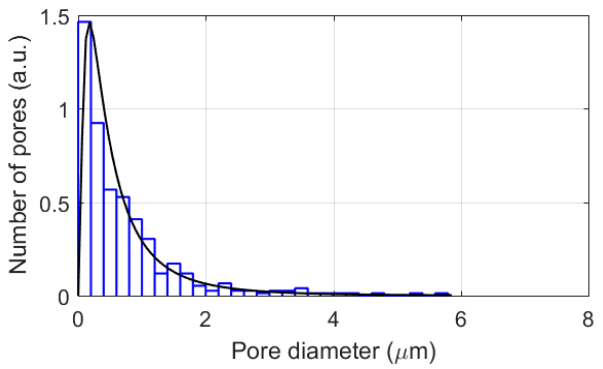

(d)

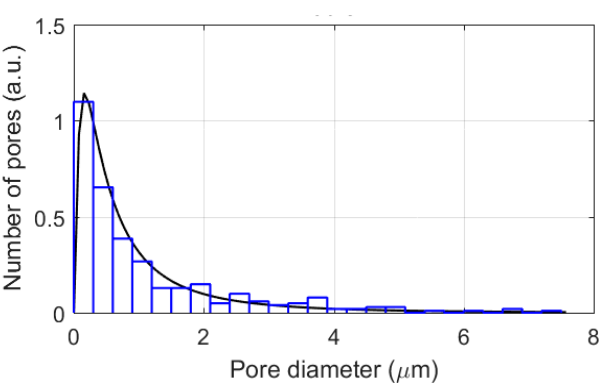

(f)

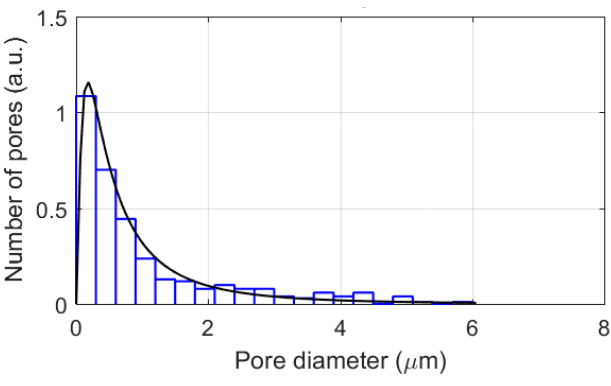

(h)

Figure 2. Surface morphology, coating cross-sections, and corresponding pore size distributions (with lognormal distribution fit) for the different PEO treatment times: (a,b) 45 s; (c,d) 60 s; (e,f) 90 s; $(\mathbf{g}, \mathbf{h}) 120 \mathrm{~s}$. 


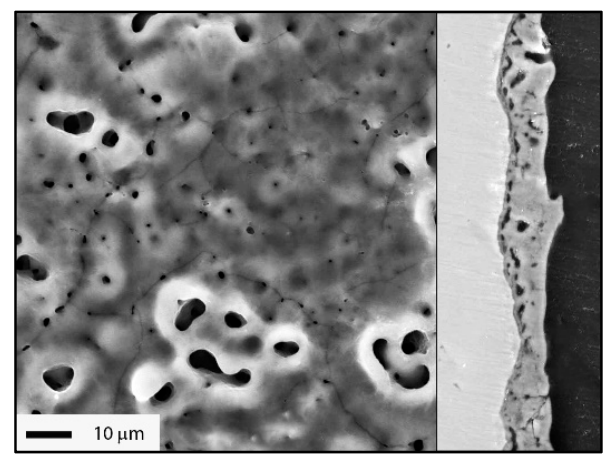

(a)

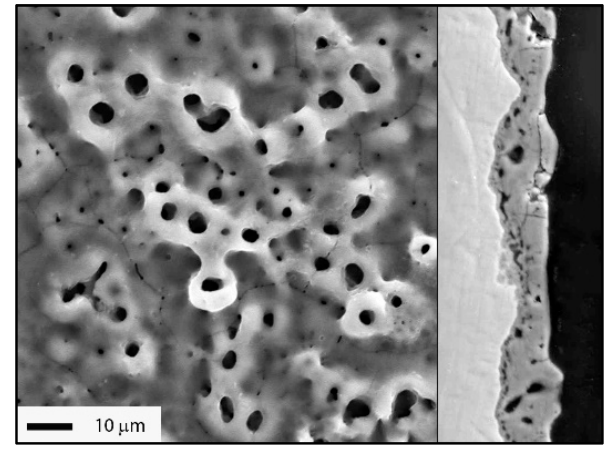

(c)

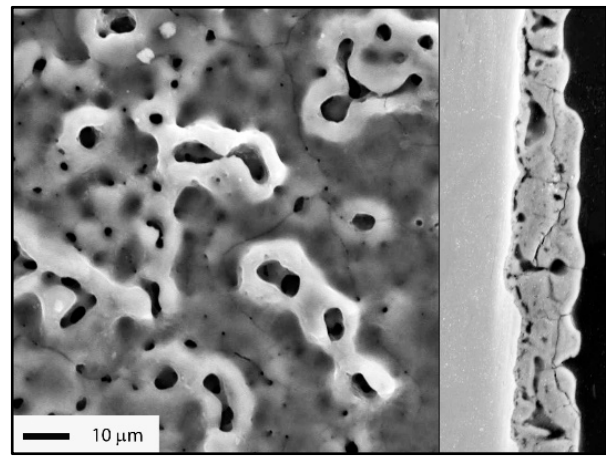

(e)

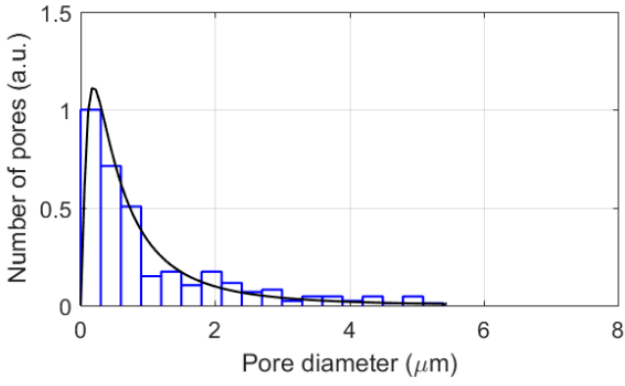

(b)

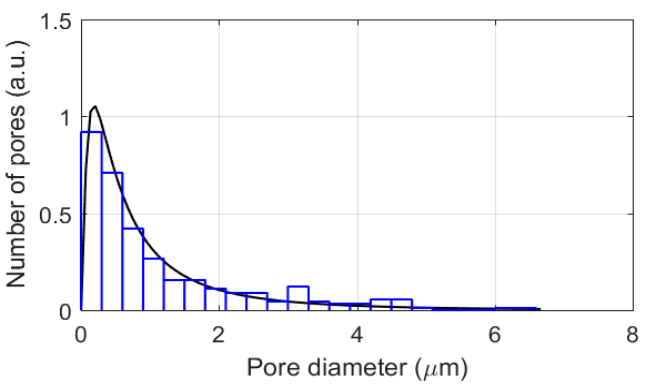

(d)

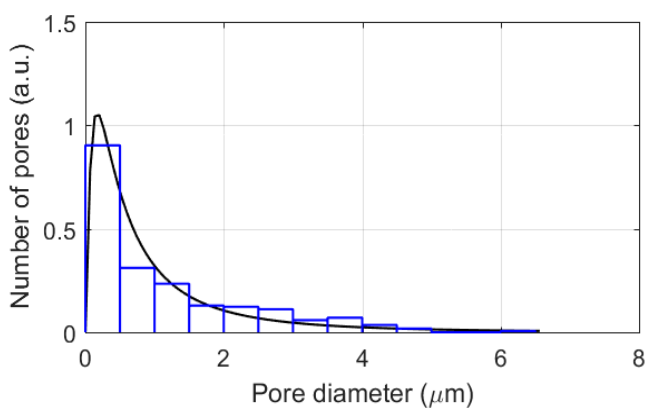

(f)

Figure 3. Surface morphology, coating cross-sections, and corresponding pore size distributions (with lognormal distribution fit) for the different PEO treatment times: (a,b) $180 \mathrm{~s}$; (c,d) $240 \mathrm{~s}$; (e,f) $300 \mathrm{~s}$.

Analysis of the numerical parameters characterizing the coatings is presented in Figure 5. The coating reached the thickness of $10 \mu \mathrm{m}$ by $120 \mathrm{~s}$ of the PEO, showing the growth rate of $5 \mu \mathrm{m} / \mathrm{min}$; further process was characterized by the rate of $0.5 \mu \mathrm{m} / \mathrm{min}$, and the coating reached a $12 \mu \mathrm{m}$ thickness by $300 \mathrm{~s}$ (Figure 5a). The surface roughness followed the coating thickness change: Ra rapidly grew from 0.1 to $1.0 \mu \mathrm{m}$ during $120 \mathrm{~s}$, and then gradually reached $1.3 \mu \mathrm{m}$ by $300 \mathrm{~s}$ (Figure 5b). The peak height $\mathrm{Rp}$ and valley depth $\mathrm{Rv}$ also increased (Figure $5 \mathrm{~d}$ ); the Rp reached $5 \mu \mathrm{m}$ by $120 \mathrm{~s}$ and a further $8 \mu \mathrm{m}$ by $300 \mathrm{~s}$. The maximal value depth was $4 \mu \mathrm{m}$, which comprises one third of the coating thickness. 


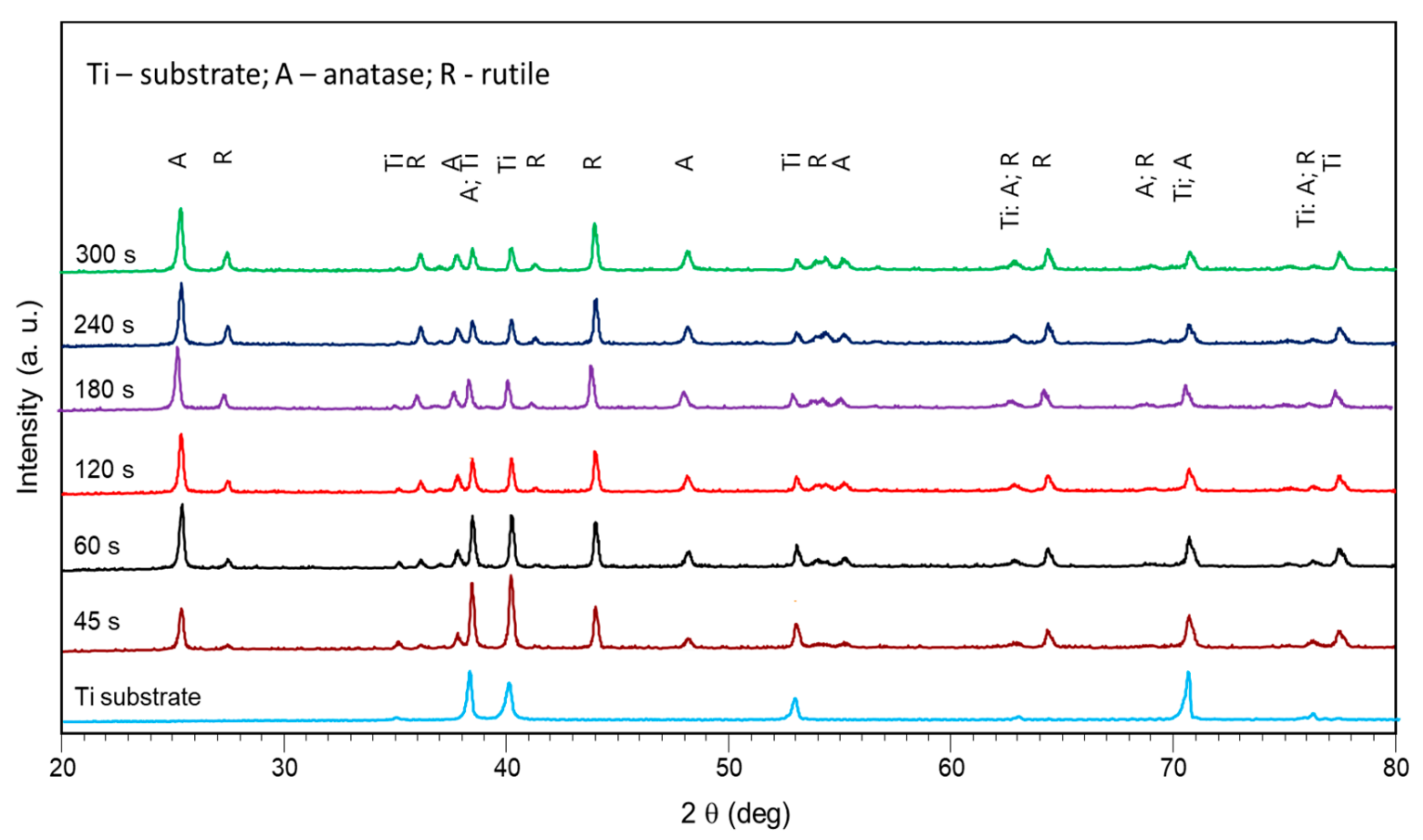

Figure 4. X-ray diffractograms of the coated Ti for the different PEO treatment times.

The coating porosity almost linearly increased with the PEO treatment time (Figure 5c); starting with $2-3 \%$ at $45-60 \mathrm{~s}$, it reached $6 \%$ by $300 \mathrm{~s}$. The mean pore diameter obtained from the lognormal distribution increased from 0.7 to $1.2 \mu \mathrm{m}$ during the treatment (Figure 5e). The content of the anatase linearly decreased with the treatment time (Figure 5f) starting from $83 \%$ at $45 \mathrm{~s}$ to $63 \%$ at $300 \mathrm{~s}$. It should be pointed out that at $90 \mathrm{~s}$ of the PEO, all the analyzed parameters showed a deviation toward the increase over the general regularity: the coating thickness, roughness, porosity, and pore diameter were significantly higher than expected. Compared with the current density (Figure 1a), we can expect this to be an effect of the current peak ranging from 30 to $120 \mathrm{~s}$ when the current density is higher than the passivation current density value between 10 and $20 \mathrm{~s}$.

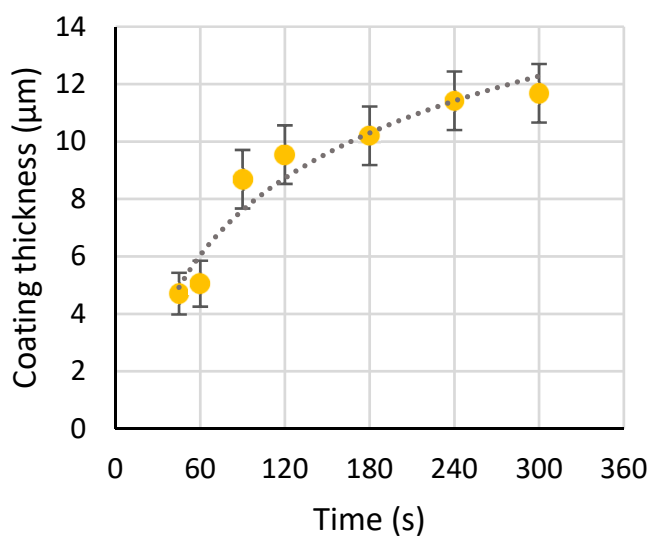

(a)

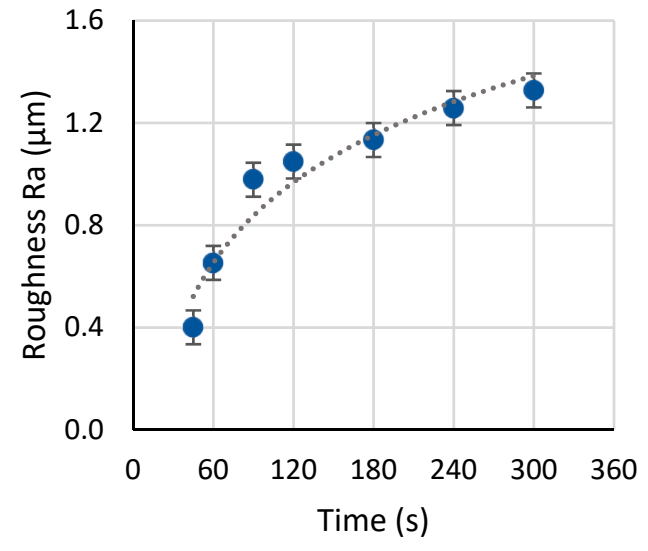

(b)

Figure 5. Cont. 


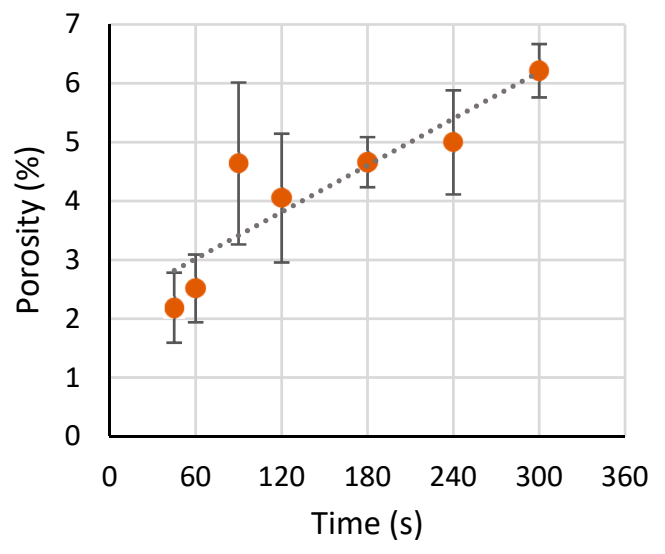

(c)

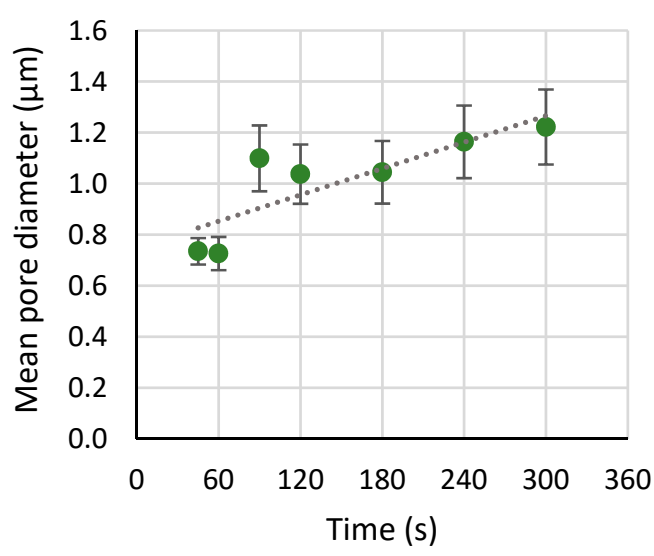

(e)

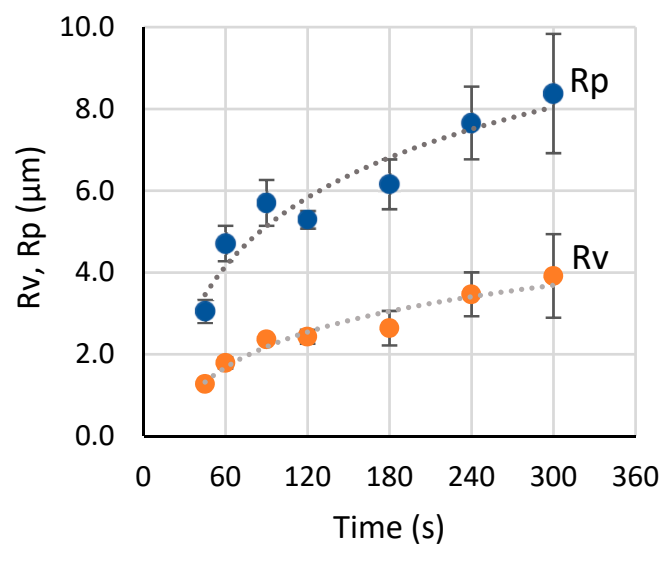

(d)

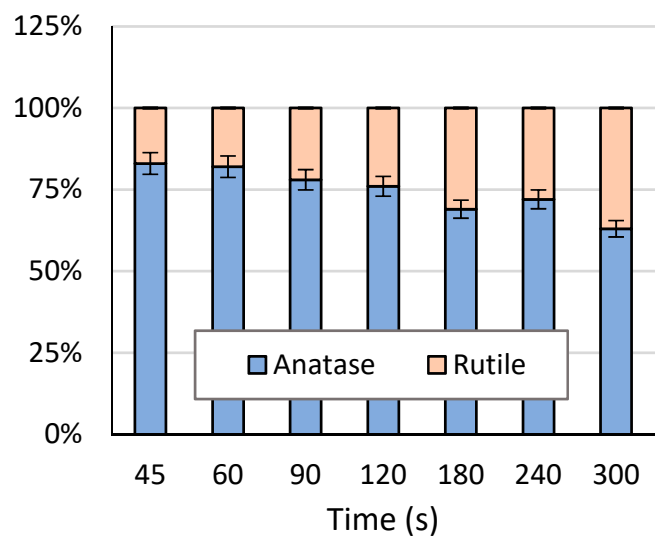

(f)

Figure 5. Coating properties vs. PEO treatment times: (a) coating thickness; (b) surface roughness $\mathrm{Ra}$; (c) porosity; (d) peak height Rp and valley depth Rv; (e) mean pore diameter obtained from the lognormal distribution; (f) anatase and rutile content in the coating.

\subsection{Evolution of Optical Emission Spectra during PEO of Ti}

Figure 6 shows the evolution of the optical emission spectra of the microdischarges during the PEO of Ti. The spectra comprise characteristic peaks belonging to the elements of the electrolyte and the substrate, and a halo background due to the dissipation in the electrolyte bulk [49]. The strongest Na I peak at $589 \mathrm{~nm}$ provides the yellow color of the microdischarges; this peak grew with the treatment time, and its measurements were saturated at the maximal value of the sensor. Therefore, for the application of the method described in Section 2.3, another Na peak was used (Na II at $818 \mathrm{~nm}$ ) to represent the electrolyte component. The titanium substrate was characterized by a Ti I peak at $453 \mathrm{~nm}$ as the strongest one available in the spectrum. The evolution of the intensities of the selected peaks is shown in Figure $6 \mathrm{~b}, \mathrm{c}$. The electrolyte component line generally grows; between 30 and $90 \mathrm{~s}$, it exhibited a peak following the peak of the current density (Figure 1a). The substrate line decreased after the same peak. Similar spectral peak evolutions were presented elsewhere [50]; however, no conclusions toward the connection with the coating thickness were made in that work. 


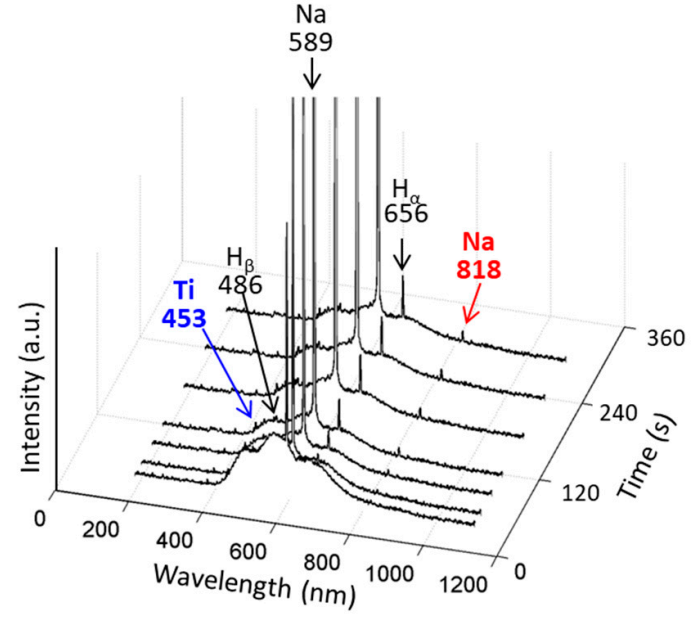

(a)

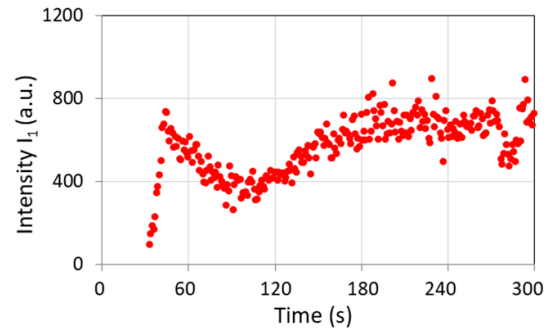

(b)

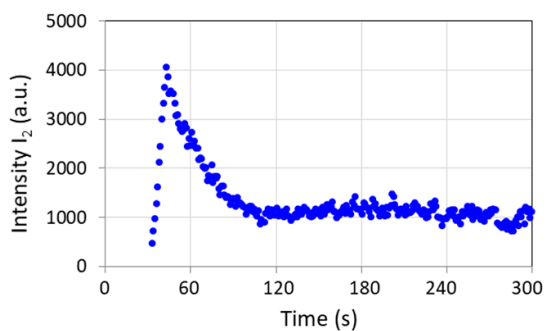

(c)

Figure 6. Optical emission spectra of microdischarges during the PEO of Ti: (a) overview of the optical emission spectra evolution; (b) intensity $I_{1}$ for Na II $(817.986 \mathrm{~nm})$ representing the component of the electrolyte; (c) intensity $I_{2}$ for Ti I (453.501 nm) representing the substrate.

\subsection{Evolution of In Situ Impedance Spectra during PEO of Ti}

In Figure 7, in situ impedance spectra of the PEO process during formation of the coating on $\mathrm{Ti}$ are represented by the experimental data and fit results. Based on earlier results $[41,48]$, the understanding of the equivalent circuits describing the PEO process was enhanced. The complex plots of the in situ impedance spectra had an irregular semicircular shape appearing in the capacitive half-plane. The approximation toward the highest frequencies corresponded to Rs as the electrolyte solution resistance had a zero phase shift.

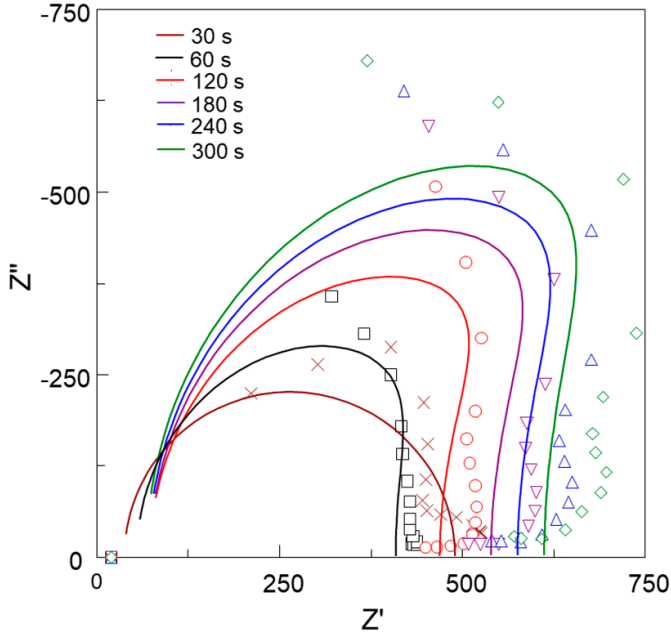

(a)

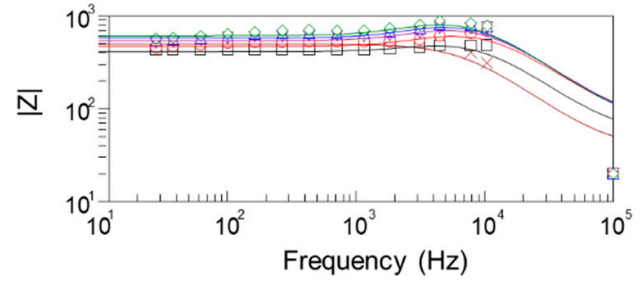

(b)

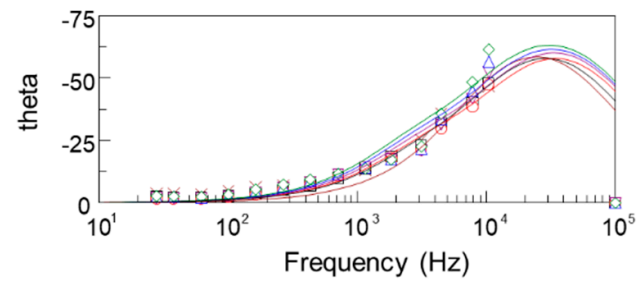

(c)

Figure 7. In situ impedance spectra of the PEO process during formation of the coating on Ti with the experimental data and fit results: (a) complex plot; (b) Bode plot for the impedance modulus; (c) Bode plot for the impedance phase angle. 
The impedance spectra fitting was performed using first- and second-order ladder equivalent circuits (Figure 8). Since the PEO process during the first 30 s comprises mainly anodizing, the first-order Randles circuit was used (Figure 8a) [51]. As the semi-circle in the complex plot bends inside at the lowest frequencies, it is expected to have a RC pair with a negative time constant standing for a negative differential resistance (NDR) of the microdischarges [48]. The fit results are shown in Table 1; for all fits, the electrolyte resistance was the same Rs $=23.5 \pm 13.2 \Omega$.

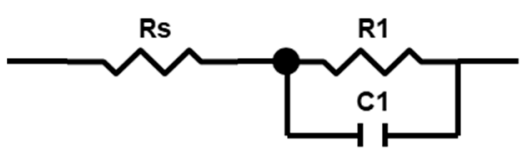

(a)

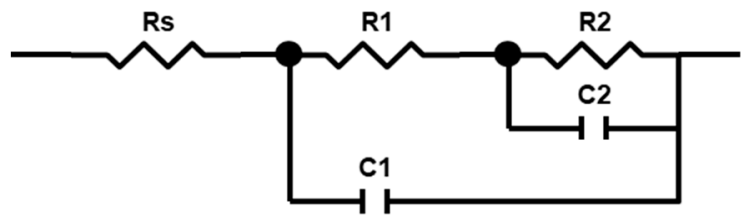

(b)

Figure 8. Equivalent circuit for the fitting of the in situ impedance spectra of Ti PEO at different stages: (a) $30 \mathrm{~s}$; (b) 60-300 s.

Table 1. Equivalent circuit fit results for the in situ impedance spectroscopy of Ti PEO.

\begin{tabular}{|c|c|c|c|c|c|}
\hline $\begin{array}{l}\text { Time } \\
\text { (s) }\end{array}$ & $\begin{array}{c}R 1 \\
\left(\Omega \mathrm{cm}^{2}\right)\end{array}$ & $\begin{array}{c}\mathrm{C} 1 \\
\left(\mathrm{~F} \cdot \mathrm{cm}^{-2} \cdot 10^{-8}\right)\end{array}$ & $\begin{array}{c}R 2 \\
\left(\Omega \mathrm{cm}^{2}\right)\end{array}$ & $\begin{array}{c}\mathrm{C} 2 \\
\left(\mathrm{~F} \cdot \mathrm{cm}^{-2} \cdot 10^{-8}\right)\end{array}$ & Chi-Sqr \\
\hline 30 & $452.1 \pm 24.7$ & $5.11 \pm 0.61$ & - & - & 0.399 \\
\hline 60 & $614.9 \pm 140.5$ & $3.09 \pm 0.63$ & $-260.0 \pm 144.1$ & $14.40 \pm 18.79$ & 0.333 \\
\hline 120 & $824.0 \pm 201.5$ & $1.94 \pm 0.51$ & $-427.2 \pm 208.5$ & $7.43 \pm 8.54$ & 0.381 \\
\hline 180 & $962.1 \pm 226.6$ & $1.84 \pm 0.45$ & $-496.6 \pm 232.2$ & $6.96 \pm 7.67$ & 0.366 \\
\hline 240 & $1063.0 \pm 247.7$ & $1.83 \pm 0.42$ & $-558.2 \pm 252.1$ & $6.52 \pm 6.91$ & 0.352 \\
\hline 300 & $1170.0 \pm 275.3$ & $1.84 \pm 0.41$ & $-626.6 \pm 278.4$ & $6.03 \pm 6.26$ & 0.345 \\
\hline
\end{tabular}

As seen in Table 1, the values of R2 were negative, and they increased in absolute values. The coating resistance R1 increased with the treatment time from 450 to $1200 \Omega \cdot \mathrm{cm}^{2}$. Similar values were obtained earlier using another type of sweep, and with a Voight-type equivalent circuit fitting [41]. The coating capacitance $\mathrm{C} 1$ decreased rapidly during the first $120 \mathrm{~s}$ and then stabilized at $1.8 \times 10^{-8} \mathrm{~F} \cdot \mathrm{cm}^{-2}$. C2 followed the same pattern.

\section{Discussion}

Analysis of the surface properties during the PEO process shows that the titania PEO coating growth on $\mathrm{cp}$-Ti undergoes the stages of anodic dissolution, passivation, spark microdischarge ignition, microdischarge development, and growth. These stages are reflected as certain regions in the current density plot. This regime results in the porous PEO coating morphology that appears to form within the first $120 \mathrm{~s}$ of the treatment when the current density is higher than the passivation value. The coating thickness appears within the range 10-12 $\mu \mathrm{m}$ after $300 \mathrm{~s}$ of the treatment. The coating exhibited roughness in the range 0.7-1.4 $\mu \mathrm{m}$ suitable for the osseointegration, as shown elsewhere [52,53]. However, a notable linear growth appeared in the porosity, mean pore diameter, and the rutile content. The coating porosity appeared in the range $4-6 \%$ after $120 \mathrm{~s}$; the mean pore diameter was 1.1-1.2 $\mu \mathrm{m}$ throughout 120-300 s of the PEO. The anatase, being the more favorable phase for coating biocompatibility [54], decreased in its content during the process; however, at $120 \mathrm{~s}$, it still comprises over $75 \%$ of the coating. As shown elsewhere, rutile must also appear in the coating to provide optimum performance [53].

Analysis of the in situ optical emission spectroscopy results supports the understanding that the substrate line intensities decrease with the PEO treatment time as the coating gains its thickness; this is consistent with other studies of the PEO under voltage control [27], indicating that the substrate emission is blocked by the growing coating. Larger microdischarges provide higher energy for the electrolyte species excitation; therefore, the 
spectral lines for the electrolyte components grow with the increase in the energy of a single microdischarge for the thicker coating.

Following the understanding of the PEO mechanism where the microdischarges break down the layer having the most dielectric strength, which is the barrier layer on the coating bottom where the microdischarge develops [55], and it is the substrate species that generates the emission first. Therefore, the pore filled with the electrolyte liquid or vapor is ionized after the breakdown of the barrier layer, and the electrolyte species also generate the emission. With the coating growth, the depth of the pores increases, so the intensity of the electrolyte species emission increases. On the other hand, the thickness of the barrier layer does not change with time, and the substrate material emission is masked, and its characteristic line intensity decreases.

These regularities support the possibility of indirectly measuring the coating thickness $h$ and other correlated properties ( $R a, R p, R v)\left(R^{2}\right.$ values are in the range 0.92-0.95) via a calibration line with the logarithmic ratio of the characteristic line intensities $\ln \left(I_{1} / I_{2}\right)$ (Figure $9 \mathrm{~b}$ ). It should be pointed out that the temporal resolution of this method corresponds to the spectrum integration time $(1 \mathrm{~s})$, and is significantly finer than that of in situ impedance spectroscopy ( $30 \mathrm{~s}$ ), therefore, Figure $9 \mathrm{a}$ contains a larger number of the experimental points compared to Figure 9c,e. The optical emission characteristics and the coating thickness reached a steady state at $120 \mathrm{~s}$ of the treatment; therefore, this duration can be recommended for the termination of the PEO process.

Analysis of the in situ impedance spectroscopy results showed that the proposed equivalent circuit can be a useful tool for the estimation of the process stages and of the coating thickness and other correlated properties. The passivation stage of the process ( $0-30 \mathrm{~s})$ can be described with a first order Randles circuit comprising the electrolyte resistance, charge transfer resistance $\mathrm{R} 1$, and barrier layer capacitance $\mathrm{C} 1$. The ladder structure of the circuit, in combination with the negative differential resistance R2, reflect recent understanding of the PEO process mechanism, discussed elsewhere [40]. This supports the hypothesis that the microdischarges do not penetrate the whole thickness of the coating; instead, they break down the inner dense PEO coating layer as having the most dielectric strength. Therefore, the pair R2C2 has an NDR element standing for the microdischarge conductive channel. In contrast, the pore channel in this case is filled with a conductive media — either liquid or vaporized electrolyte [55] — and the pair R1C1 exhibits a positive differential resistance (Figure 10a).

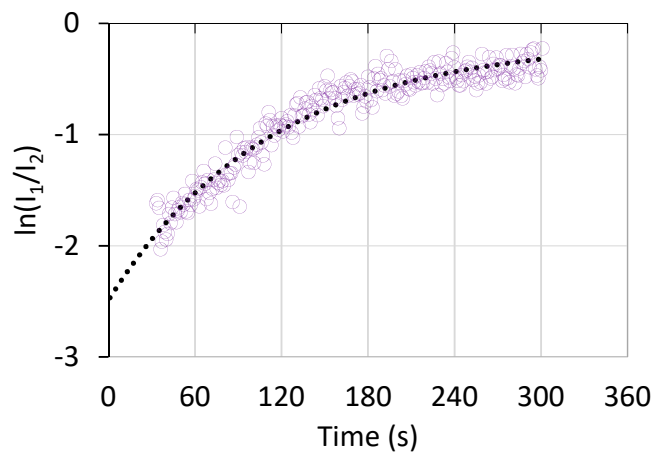

(a)

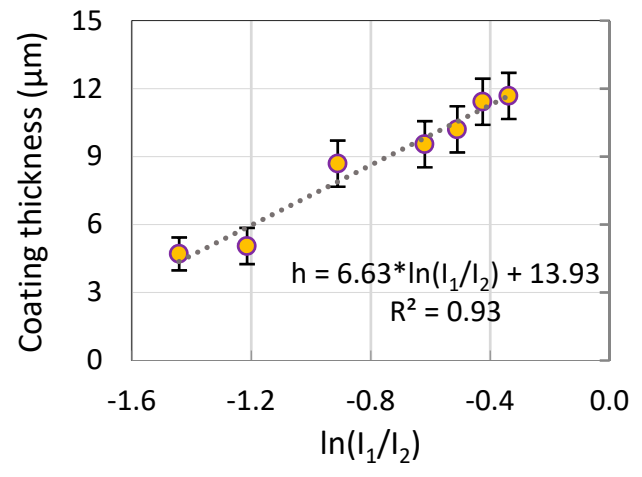

(b)

Figure 9. Cont. 


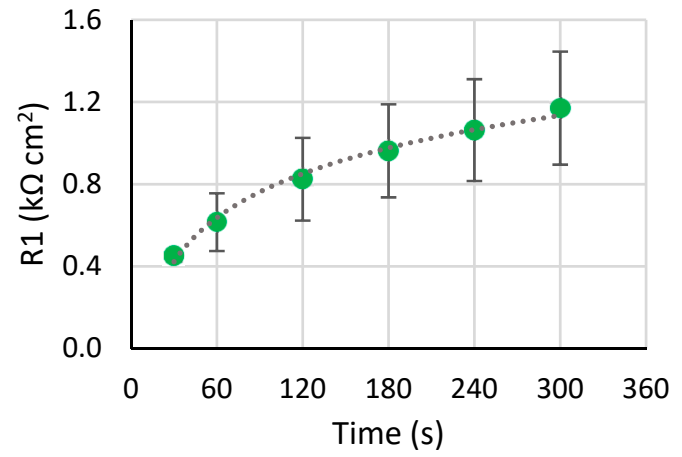

(c)

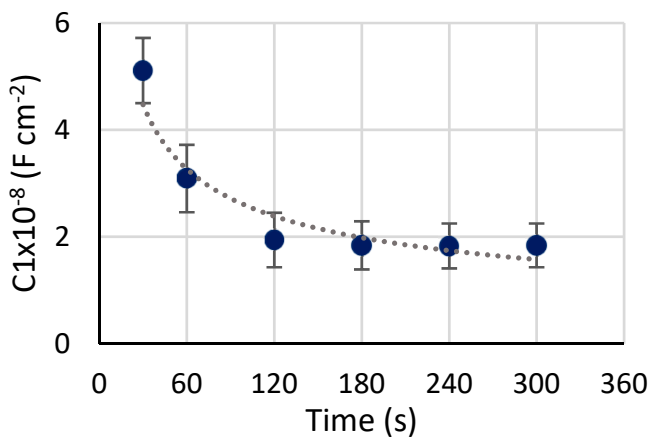

(e)

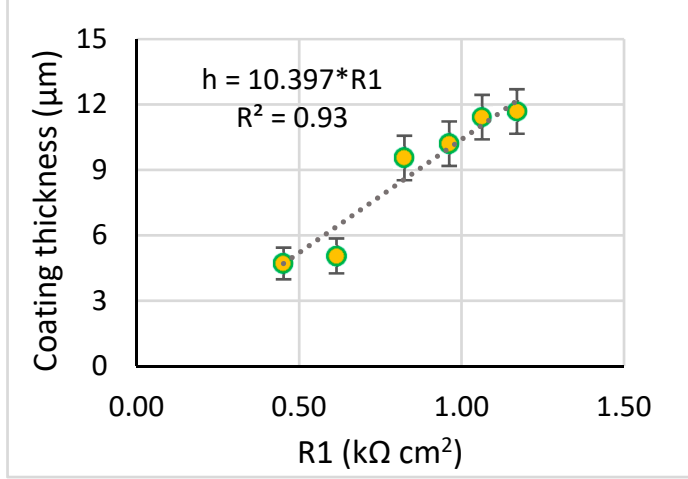

(d)

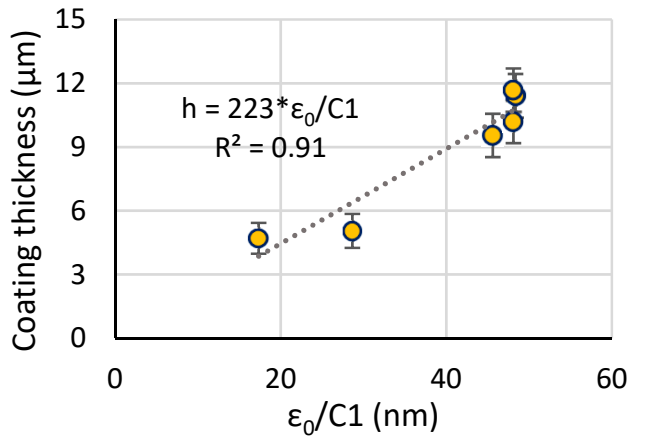

$(\mathbf{f})$

Figure 9. In situ parameters characterizing the Ti PEO, and calibration lines for the coating thickness estimation: (a) evolution of $\ln \left(I_{1} / I_{2}\right)$ calculated from the optical emission; (b) calibration line for the coating thickness estimation via the optical emission method; (c) evolution of R1 calculated from the in situ impedance spectroscopy; (d) calibration line for the coating thickness estimation via R1; (e) evolution of $\mathrm{C} 1$ calculated from the in situ impedance spectroscopy; (f) calibration line for the coating thickness estimation via $\mathrm{C} 1$.

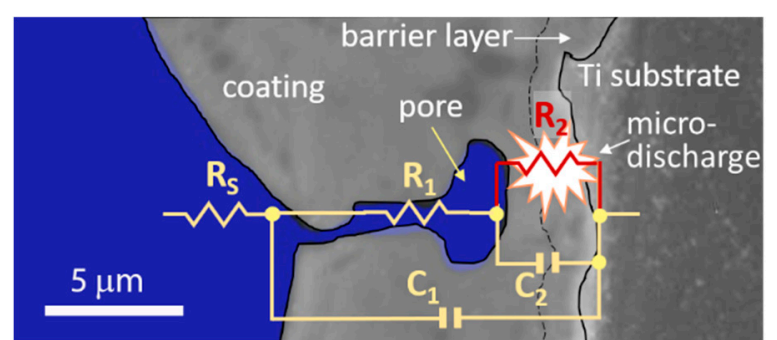

(a)

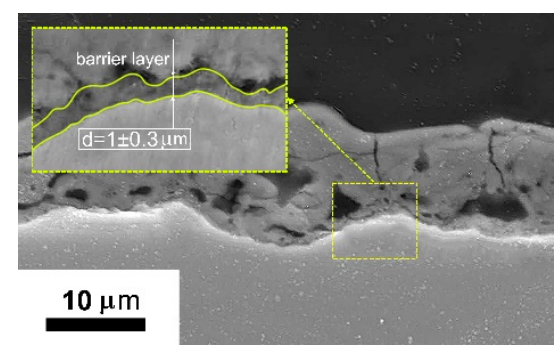

(b)

Figure 10. Typical PEO coating cross-section after $180 \mathrm{~s}$ of the treatment: (a) in situ equivalent circuit corresponding to the PEO process mechanism; (b) barrier layer of the PEO coating.

The evolution of the coating resistance R1 was correlated with both the coating thickness and roughness $\mathrm{Ra}\left(\mathrm{R}^{2}\right.$ values were 0.93 and 0.96 respectively); their values increased with time at the same rate (Figures $5 \mathrm{a}, \mathrm{b}$ and $9 \mathrm{c}, \mathrm{d}$ ). The calibration line shows that each $\mathrm{k} \Omega \cdot \mathrm{cm}^{2}$ of $\mathrm{R} 1$ stands for $10.4 \mu \mathrm{m}$ of the resultant coating.

As the dielectric film thickness $h$ is inversely proportional to its capacitance per unit area:

$$
h=\frac{\varepsilon \varepsilon_{0}}{\mathrm{C}} \text {, where } \varepsilon_{0}=8.85 \cdot 10^{-12} \mathrm{~F} \cdot \mathrm{m}^{-1},
$$


the correlation of the coating thickness with $\varepsilon_{0} / \mathrm{C} 1$ was also considered (Figures $5 \mathrm{a}$ and $9 \mathrm{e}, \mathrm{f}$ ). The capacitance $\mathrm{C} 1$ did not change in the time interval from 120 to $300 \mathrm{~s}$ of the PEO, indicating the same dielectric properties of the coating. Direct assessment of Equation (3) yielded the value of the coating permittivity $\varepsilon$ in the range 200-250. This is consistent by the order of magnitude with the estimates for rutile in [56] and for anatase in [57]; however, it was 5-fold higher than the estimate of anodic titania film permittivity $\varepsilon=45$ [58].

The values of $\mathrm{C} 2$ appeared in the range of the $\mathrm{Cdl}$ evaluated and correlated with the barrier layer thickness via (3) earlier [41]. The steady state value of $C 2=6.5 \cdot 10^{-8} \mathrm{~F} \cdot \mathrm{cm}^{-2}$ corresponds to the barrier layer thickness $\mathrm{d}=0.6 \mu \mathrm{m}$ if using anodic titania film permittivity $\varepsilon=45$. This is consistent with a typical coating cross-section (Figure 10b). Consequently, further understanding of the capacitance estimates' correlation with the coating properties needs separate research.

As a result, the proposed equivalent circuit decomposes the frequency response and provides the elements where physical meaning and evolution correspond to the resultant coating properties (Figure 10b). In this study, the PEO process time of $120 \mathrm{~s}$ appeared to be a beneficial trade-off between the coating morphology suitable for the realization of the biomimetic approach, and the energy-consuming process duration.

The analyzed and justified in situ spectroscopic methods help to correct the treatment time in the vicinity of $120 \mathrm{~s}$ with a process control and diagnostic system when the coating precisely achieves the desired properties.

\section{Conclusions}

- The plasma electrolytic oxidation in the pulsed bipolar mode under the voltage control, comprising a ramp for the soft start and a steady state regime, provided the active coating growth on cp-Ti for up to $120 \mathrm{~s}$ of treatment. After this time, the coating growth rate decreased 10-fold, and up to $300 \mathrm{~s}$, the coating thickness, roughness, and morphology did not change significantly. In the time range from 120 to $300 \mathrm{~s}$, a notable linear growth appeared in the rutile content due to an increase in the power of the microdischarges. Given that for the biocompatibility, the anatase should prevail in the coating composition, the increase in the treatment time is not necessary after $120 \mathrm{~s}$. This coating is suitable for the realization of the biomimetic approach, and it can serve as an inorganic matrix for further introduction of bioactive organic molecules.

- The intensities of the spectral lines of the substrate material, and of the electrolyte species present in the emission generated by the microdischarges changed with the coating growth. Since the spectral line of the substrate material decreases, this supports the contribution to the PEO process mechanism understanding that the breakdown occurs in the barrier layer. Since the electrolyte species' spectral lines grow, this justifies the ionization of the electrolyte vapor in the deepening coating pore.

- As a result, an optical method was proposed and justified for the coating thickness estimation. The method comprises the log scale ratio of the electrolyte component emission intensity over the substrate material emission intensity; this ratio is highly correlated with the coating thickness and roughness $\left(R^{2}>0.92\right)$, therefore, the coating properties can be estimated during the PEO treatment.

- The in situ impedance spectroscopy helped to evaluate the PEO process frequency response and to propose the underlying equivalent circuit. The microdischarge ignition changed the impedance spectra so that a negative time constant appeared in the system. The impedance spectra fitting with a ladder circuit showed that the negative differential resistance belongs to the inner barrier layer of the coating where the microdischarge starts the breakdown.

- The correlation was established between the resistance $\mathrm{R} 1,1 / \mathrm{C} 1$, and the coating thickness and roughness $\left(R^{2}>0.93\right)$, therefore, the coating properties can be estimated during the PEO treatment with this method. The evolution of the equivalent circuit parameters showed that after $120 \mathrm{~s}$ of the PEO, no significant changes appeared, therefore, this time can be recommended for the coating formation. 
- Two analyzed and justified in situ spectroscopic methods help to correct the treatment time in the vicinity of $120 \mathrm{~s}$ when the coating precisely achieves the required properties by using an appropriately designed process control and diagnostic system.

Author Contributions: Conceptualization, V.A., L.P. and E.P.; Methodology, R.F.; Investigation, V.A., A.S. and R.F.; Resources, A.S. and V.P.; Data curation, R.F. and E.P.; Writing-original draft preparation, V.A.; Writing-review and editing, E.P. and L.P.; Visualization, V.P.; Supervision, E.P. All authors have read and agreed to the published version of the manuscript.

Funding: This research was funded by the Russian Science Foundation, grant number 19-49-02003.

Institutional Review Board Statement: Not applicable.

Informed Consent Statement: Not applicable.

Data Availability Statement: Data are available upon request from the corresponding author.

Acknowledgments: The surface characterization was performed at the Center of Collective Usage of Scientific Equipment "Nanotech" at Ufa State Aviation Technical University, and this support is acknowledged with thanks.

Conflicts of Interest: The authors declare no conflict of interest.

\section{References}

1. Geetha, M.; Singh, A.K.; Asokamani, R.; Gogia, A.K. Ti based biomaterials, the ultimate choice for orthopaedic implants-A review. Prog. Mater. Sci. 2009, 54, 397-425. [CrossRef]

2. Sam Froes, F.H.; Qian, M. Titanium background, alloying behavior and advanced fabrication techniques-An overview. In Titanium in Medical and Dental Applications; Elsevier: Amsterdam, The Netherlands, 2018; pp. 23-37. [CrossRef]

3. Parfenov, E.V.; Parfenova, L.V.; Dyakonov, G.S.; Danilko, K.V.; Mukaeva, V.R.; Farrakhov, R.G.; Lukina, E.S.; Valiev, R.Z. Surface functionalization via PEO coating and RGD peptide for nanostructured titanium implants and their in vitro assessment. Surf. Coat. Technol. 2019, 357, 669-683. [CrossRef]

4. Echeverry-Rendón, M.; Galvis, O.; Aguirre, R.; Robledo, S.; Castaño, J.G.; Echeverría, F. Modification of titanium alloys surface properties by plasma electrolytic oxidation (PEO) and influence on biological response. J. Mater. Sci. Mater. Med. 2017, $28,169$. [CrossRef] [PubMed]

5. Zhang, X.; Wu, Y.; Lv, Y.; Yu, Y.; Dong, Z. Formation mechanism, corrosion behaviour and biological property of hydroxyapatite $/ \mathrm{TiO}_{2}$ coatings fabricated by plasma electrolytic oxidation. Surf. Coat. Technol. 2020, 386, 125483. [CrossRef]

6. Spriano, S.; Yamaguchi, S.; Baino, F.; Ferraris, S. A critical review of multifunctional titanium surfaces: New frontiers for improving osseointegration and host response, avoiding bacteria contamination. Acta Biomater. 2018, 79, 1-22. [CrossRef] [PubMed]

7. Su, Y.; Luo, C.; Zhang, Z.; Hermawan, H.; Zhu, D.; Huang, J.; Liang, Y.; Li, G.; Ren, L. Bioinspired surface functionalization of metallic biomaterials. J. Mech. Behav. Biomed. Mater. 2018, 77, 90-105. [CrossRef]

8. Liu, Z.; Liu, X.; Ramakrishna, S. Surface engineering of biomaterials in orthopedic and dental implants: Strategies to improve osteointegration, bacteriostatic and bactericidal activities. Biotechnol. J. 2021, 16, e2000116. [CrossRef]

9. Cordeiro, J.M.; Nagay, B.E.; Ribeiro, A.L.R.; da Cruz, N.C.; Rangel, E.C.; Fais, L.M.G.; Vaz, L.G.; Barão, V.A.R. Functionalization of an experimental Ti-Nb-Zr-Ta alloy with a biomimetic coating produced by plasma electrolytic oxidation. J. Alloys Compd. 2019, 770, 1038-1048. [CrossRef]

10. Aliofkhazraei, M.; Macdonald, D.D.; Matykina, E.; Parfenov, E.V.; Egorkin, V.S.; Curran, J.A.; Troughton, S.C.; Sinebryukhov, S.L.; Gnedenkov, S.V.; Lampke, T.; et al. Review of plasma electrolytic oxidation of titanium substrates: Mechanism, properties, applications and limitations. Appl. Surf. Sci. Adv. 2021, 5, 100121. [CrossRef]

11. Yerokhin, A.L.; Nie, X.; Leyland, A.; Matthews, A.; Dowey, S.J. Plasma electrolysis for surface engineering. Surf. Coat. Technol. 1999, 122, 73-93. [CrossRef]

12. Santos-Coquillat, A.; Martínez-Campos, E.; Mohedano, M.; Martínez-Corriá, R.; Ramos, V.; Arrabal, R.; Matykina, E. In vitro and in vivo evaluation of PEO-modified titanium for bone implant applications. Surf. Coat. Technol. 2018, 347, 358-368. [CrossRef]

13. Wang, Y.; Yu, H.; Chen, C.; Zhao, Z. Review of the biocompatibility of micro-arc oxidation coated titanium alloys. Mater. Des. 2015, 85, 640-652. [CrossRef]

14. Sampatirao, H.; Radhakrishnapillai, S.; Dondapati, S.; Parfenov, E.; Nagumothu, R. Developments in plasma electrolytic oxidation (PEO) coatings for biodegradable magnesium alloys. Mater. Today Proc. 2021, 46, 1407-1415. [CrossRef]

15. Parfenov, E.V.; Yerokhin, A.; Nevyantseva, R.R.; Gorbatkov, M.V.; Liang, C.J.; Matthews, A. Towards smart electrolytic plasma technologies: An overview of methodological approaches to process modelling. Surf. Coat. Technol. 2015, 269, 2-22. [CrossRef]

16. Tsai, D.S.; Chou, C.C. Review of the soft sparking issues in plasma electrolytic oxidation. Metals 2018, 8, 105. [CrossRef]

17. Lu, X.; Mohedano, M.; Blawert, C.; Matykina, E.; Arrabal, R.; Kainer, K.U.; Zheludkevich, M.L. Plasma electrolytic oxidation coatings with particle additions-A review. Surf. Coat. Technol. 2016, 307, 1165-1182. [CrossRef] 
18. Santos-Coquillat, A.; Mohedano, M.; Martinez-Campos, E.; Arrabal, R.; Pardo, A.; Matykina, E. Bioactive multi-elemental PEO-coatings on titanium for dental implant applications. Mater. Sci. Eng. C 2019, 97, 738-752. [CrossRef]

19. Kaseem, M.; Choe, H.-C. Triggering the hydroxyapatite deposition on the surface of PEO-coated Ti-6Al-4V alloy via the dual incorporation of $\mathrm{Zn}$ and $\mathrm{Mg}$ ions. J. Alloys Compd. 2020, 819, 153038. [CrossRef]

20. Ahounbar, E.; Mousavi Khoei, S.M.; Omidvar, H. Characteristics of in-situ synthesized Hydroxyapatite on $\mathrm{TiO}_{2}$ ceramic via plasma electrolytic oxidation. Ceram. Int. 2019, 45, 3118-3125. [CrossRef]

21. Pezzato, L.; Brunelli, K.; Diodati, S.; Pigato, M.; Bonesso, M.; Dabalà, M. Microstructural and corrosion properties of hydroxyapatite containing PEO coating produced on AZ31 Mg alloy. Materials 2021, 14, 1531. [CrossRef] [PubMed]

22. Parfenov, E.; Parfenova, L.; Mukaeva, V.; Farrakhov, R.; Stotskiy, A.; Raab, A.; Danilko, K.; Rameshbabu, N.; Valiev, R. Biofunctionalization of PEO coatings on titanium implants with inorganic and organic substances. Surf. Coat. Technol. 2020, 404, 126486. [CrossRef]

23. Parfenova, L.V.; Lukina, E.S.; Galimshina, Z.R.; Gil'fanova, G.U.; Mukaeva, V.R.; Farrakhov, R.G.; Danilko, K.V.; Dyakonov, G.S.; Parfenov, E.V. Biocompatible Organic Coatings Based on Bisphosphonic Acid RGD-Derivatives for PEO-Modified Titanium Implants. Molecules 2020, 25, 229. [CrossRef]

24. Matykina, E.; Arrabal, R.; Pardo, A.; Mohedano, M.; Mingo, B.; Rodríguez, I.; González, J. Energy-efficient PEO process of aluminium alloys. Mater. Lett. 2014, 127, 13-16. [CrossRef]

25. Zou, Y.; Wang, Y.; Sun, Z.; Cui, Y.; Jin, T.; Wei, D.; Ouyang, J.; Jia, D.; Zhou, Y. Plasma electrolytic oxidation induced 'local over-growth' characteristic across substrate/coating interface: Effects and tailoring strategy of individual pulse energy. Surf. Coat. Technol. 2018, 342, 198-208. [CrossRef]

26. Nadaraia, K.V.; Suchkov, S.N.; Imshinetskiy, I.M.; Mashtalyar, D.V.; Sinebrykhov, S.L.; Gnedenkov, S.V. Some new aspects of the study of dependence of properties of PEO coatings on the parameters of current in potentiodynamic mode. Surf. Coat. Technol. 2021, 426, 127744. [CrossRef]

27. Mukaeva, V.R.; Melnichuk, O.V.; Vasilev, R.A.; Lutfrakhmanov, I.M.; Parfenov, E.V. Study into initial stages of plasma electrolytic oxidation of magnesium alloy. J. Phys. Conf. Ser. 2020, 1713, 012030. [CrossRef]

28. Zhang, X.; Cai, G.; Lv, Y.; Wu, Y.; Dong, Z. Growth mechanism of titania on titanium substrate during the early stage of plasma electrolytic oxidation. Surf. Coat. Technol. 2020, 400, 126202. [CrossRef]

29. Casanova, L.; La Padula, M.; Pedeferri, M.; Diamanti, M.V.; Ormellese, M. An insight into the evolution of corrosion resistant coatings on titanium during bipolar plasma electrolytic oxidation in sulfuric acid. Electrochim. Acta 2021, 379, 138190. [CrossRef]

30. Sowa, M.; Parafiniuk, M.; Mouzêlo, C.M.S.; Kazek-Kęsik, A.; Zhidkov, I.S.; Kukharenko, A.I.; Cholakh, S.O.; Kurmaev, E.Z.; Simka, W. DC plasma electrolytic oxidation treatment of gum metal for dental implants. Electrochim. Acta 2019, 302, 10-20. [CrossRef]

31. Gowtham, S.; Arunnellaiappan, T.; Rameshbabu, N. An investigation on pulsed DC plasma electrolytic oxidation of cp-Ti and its corrosion behaviour in simulated body fluid. Surf. Coat. Technol. 2016, 301, 63-73. [CrossRef]

32. Yeung, W.K.; Reilly, G.C.; Matthews, A.; Yerokhin, A. In vitro biological response of plasma electrolytically oxidized and plasmasprayed hydroxyapatite coatings on Ti-6Al-4V alloy. J. Biomed. Mater. Res. Part B Appl. Biomater. 2013, 101, 939-949. [CrossRef] [PubMed]

33. Lederer, S.; Arat, S.; Fuerbeth, W. Influence of Process Parameters on the Tribological Behavior of PEO Coatings on CP-Titanium 4+ Alloys for Biomedical Applications. Materials 2021, 14, 5364. [CrossRef] [PubMed]

34. Mashtalyar, D.V.; Nadaraia, K.V.; Gnedenkov, A.S.; Imshinetskiy, I.M.; Piatkova, M.A.; Pleshkova, A.I.; Belov, E.A.; Filonina, V.S.; Suchkov, S.N.; Sinebryukhov, S.L.; et al. Bioactive coatings formed on titanium by plasma electrolytic oxidation: Composition and properties. Materials 2020, 13, 4121. [CrossRef]

35. Dzhurinskiy, D.; Gao, Y.; Yeung, W.K.; Strumban, E.; Leshchinsky, V.; Chu, P.J.; Matthews, A.; Yerokhin, A.; Maev, R.G. Characterization and corrosion evaluation of $\mathrm{TiO}_{2}$ :n-HA coatings on titanium alloy formed by plasma electrolytic oxidation. Surf. Coat. Technol. 2015, 269, 258-265. [CrossRef]

36. Parfenov, E.V.; Yerokhin, A.L.; Matthews, A. Frequency response studies for the plasma electrolytic oxidation process. Surf. Coat. Technol. 2007, 201, 8661-8670. [CrossRef]

37. Fatkullin, A.R.; Parfenov, E.V.; Yerokhin, A.; Lazarev, D.M.; Matthews, A. Effect of positive and negative pulse voltages on surface properties and equivalent circuit of the plasma electrolytic oxidation process. Surf. Coat. Technol. 2015, 284, 427-437. [CrossRef]

38. Mukaeva, V.R.; Kulyasova, O.B.; Farrakhov, R.G.; Parfenov, E.V.; Zheng, Y.F. Diagnostics of the thickness of a plasma electrolytic oxidation coating on a nanostructured Mg-Sr alloy. IOP Conf. Ser. Mater. Sci. Eng. 2018, 292, 012067. [CrossRef]

39. Gorbatkov, M.V.; Parfenov, E.V.; Mukaeva, V.R.; Zhernakov, S.V.; Yerokhin, A.L. A coating thickness measuring technic during plasma electrolytic oxidation based on optical emission spectra. Datchiki I Sist. 2018, 1, 36-39.

40. Rogov, A.B.; Huang, Y.; Shore, D.; Matthews, A.; Yerokhin, A. Toward rational design of ceramic coatings generated on valve metals by plasma electrolytic oxidation: The role of cathodic polarisation. Ceram. Int. 2021, 47, 34137-34158. [CrossRef]

41. Yerokhin, A.; Parfenov, E.V.; Matthews, A. In situ impedance spectroscopy of the plasma electrolytic oxidation process for deposition of Ca- and P-containing coatings on Ti. Surf. Coat. Technol. 2016, 301, 54-62. [CrossRef]

42. Gorbatkov, M.V.; Parfenov, E.V.; Yerokhin, A.L.; Mukaeva, V.R. Method for Coating Thickness Measurement during the Process of Plasma Electrolytic Oxidation, and a Device for Its Implementation. Russian Patent 2672036, 8 November 2018. 
43. Parfenov, E.V.; Yerokhin, A. Methodology of data acquisition and signal processing for frequency response evaluation during plasma electrolytic surface treatments. In Process Control: Problems, Techniques and Applications; Nova Science Publishers: New York, NY, USA, 2011; pp. 63-96.

44. Yerokhin, A.; Parfenov, E.V.; Liang, C.J.; Mukaeva, V.R.; Matthews, A. System linearity quantification for in-situ impedance spectroscopy of plasma electrolytic oxidation. Electrochem. Commun. 2013, 27, 137-140. [CrossRef]

45. Mukaeva, V.R.; Gorbatkov, M.V.; Farrakhov, R.G.; Lazarev, D.M.; Stotskiy, A.G.; Parfenov, E.V. Advanced plasma electrolysis research equipment with in-situ process diagnostics. In Proceedings of the 2020 International Conference on Electrotechnical Complexes and Systems (ICOECS), Ufa, Russia, 27-30 October 2020; pp. 1-4. [CrossRef]

46. Gardner, W.A. Statistical Spectral Analysis-A Nonprobabilistic Theory; Prentice Hall: Davis, CA, USA, 1987 ; p. 566.

47. Shen, V.K.; Siderius, D.W.; Krekelberg, W.P.; Hatch, H.W. NIST Standard Reference Database 78; National Institute of Standards and Technology: Gaithersburg, MD, USA, 2021; p. 20899. [CrossRef]

48. Yerokhin, A.; Mukaeva, V.R.; Parfenov, E.V.; Laugel, N.; Matthews, A. Charge transfer mechanisms underlying Contact Glow Discharge Electrolysis. Electrochim. Acta 2019, 312, 441-456. [CrossRef]

49. Hussein, R.O.; Nie, X.; Northwood, D.O.; Yerokhin, A.; Matthews, A. Spectroscopic study of electrolytic plasma and discharging behaviour during the plasma electrolytic oxidation (PEO) process. J. Phys. D-Appl. Phys. 2010, 43, 105203. [CrossRef]

50. Aliasghari, S.; Skeldon, P.; Thompson, G.E. Plasma electrolytic oxidation of titanium in a phosphate/silicate electrolyte and tribological performance of the coatings. Appl. Surf. Sci. 2014, 316, 463-476. [CrossRef]

51. Barsukov, E.; Macdonald, J.R. Impedance Spectroscopy: Theory, Experiment, and Applications, 2nd ed.; John Willey \& Sons, Inc.: Hoboken, NJ, USA, 2005; p. 616.

52. Jung, O.; Smeets, R.; Kopp, A.; Porchetta, D.; Hiester, P.; Heiland, M.; Friedrich, R.E.; Precht, C.; Hanken, H.; Gröbe, A.; et al PEO-generated Surfaces Support Attachment and Growth of Cells In Vitro with No Additional Benefit for Micro-roughness in Sa (0.2-4 $\mu \mathrm{m})$. In Vivo 2016, 30, 27-33. [PubMed]

53. Sul, Y.T.; Johansson, C.; Wennerberg, A.; Cho, L.R.; Chang, B.S.; Albrektsson, T. Optimum surface properties of oxidized implants for reinforcement of osseointegration: Surface chemistry, oxide thickness, porosity, roughness, and crystal structure. Int. J. Oral Maxillofac. Implant. 2005, 20, 349-359.

54. He, J.; Zhou, W.; Zhou, X.; Zhong, X.; Zhang, X.; Wan, P.; Zhu, B.; Chen, W. The anatase phase of nanotopography titania plays an important role on osteoblast cell morphology and proliferation. J. Mater. Sci. Mater. Med. 2008, 19, 3465-3472. [CrossRef]

55. Clyne, T.W.; Troughton, S.C. A review of recent work on discharge characteristics during plasma electrolytic oxidation of various metals. Int. Mater. Rev. 2018, 64, 127-162. [CrossRef]

56. Bonkerud, J.; Zimmermann, C.; Weiser, P.M.; Vines, L.; Monakhov, E.V. On the permittivity of titanium dioxide. Sci. Rep. 2021, 11, 12443. [CrossRef]

57. Dervos, C. Permittivity properties of thermally treated $\mathrm{TiO}_{2}$. Mater. Lett. 2004, 58, 1502-1507. [CrossRef]

58. Roh, B.; Macdonald, D.D. Effect of oxygen vacancies in anodic titanium oxide films on the kinetics of the oxygen electrode reaction. Russ. J. Electrochem. 2007, 43, 125-135. [CrossRef] 